\title{
URGENSI PEMBELAJARAN BAGI PENGEMBANGAN KARAKTER AKADEMIK MAHASISWA PENDIDIKAN TINGGI
}

\author{
Muhammad Amri \\ Fakultas Tarbiyah dan Keguruan UIN Alauddin Makassar \\ Jl. Sultan Alauddin No. 36 Samata, Gowa \\ Muhammadamri72@gmail.com
}

\begin{abstract}
Abstrak:
Tulisan ini didasarkan pada penelitian yang dilakukan pada tahun 2012 terhadap mahasiswa UIN Alauddin Makassar. Penelitian ini bertujuan untuk mempelajari urgensi strategi pembelajaran yang dikembangkan oleh dosen terhadap pengembangan karakter akademik mahasiswa setelah mengikuti perkuliahan. Data dihasilkan melalui kuisioner yang isinya dikonstruk untuk mengukur efek strategi pembelajaran terhadap peningkatan sikap ilmiah di kalangan mahasiswa. Hasilnya dianalisis dan dirujuk untuk menjelaskan strategi yang dibutuhkan untuk mengoptimalkan pencapaian tujuan pembentukan karakter akademik yang dimaksud. Sehingga dengan demikian, penelitian ini dapat dikategorikan ke dalam jenis penelitian bercampur antara kuantitatif dan kualitatif. Temuan penelitian ini menggambarkan lemahnya desain strategi pembelajaran sehingga kurang berpengaruh terhadap pembentukan sikap akademik mahasiswa.
\end{abstract}

\begin{abstract}
:
This writing based on the research conducted on 2012 at the students of state university of Alauddin Makassar. This study aims at finding the urgency of teaching strategy developed by lecturer toward students' academic character after having lecture. Data got through questionnaire constructed to measure the effect of teaching strategy toward the increasing of students' scientific attitude. Data were analyzed and referenced to explain strategy which is needed to optimalize the building those academic characters. Therefore, this study is categorized into mix method, qualitative and quantitative method. The result of this study shows that the design of teaching strategies are still low, therefore they do not affect significantly to build students' academic attitude.
\end{abstract}

\section{Kata Kunci:}

Pembentukan karakter, Akademik, Strategi pembelajaran

TEMA pendidikan diyakini sebagai tema kunci dalam membangun peradaban modern oleh karena perannya sebagai pusat perubahan yang konstruktif belum tergantikan di dunia manapun hingga saat ini. Meski demikian, perhatian terhadap sektor pendidikan belumlah semaksimal pilar peradaban lain seperti teknologi, suatu disiplin yang lahir dari kemajuan pendidikan.

Kenyataan itu menarik pengamatan Sizer yang menyatakan bahwa "Sebuah kualitas yang aneh dalam pendidikan adalah bahwa, sementara kebanyakan orang mengalaminya secara pribadi, hanya segelintir yang mempelajarinya secara serius" $.{ }^{1} \mathrm{~Pa}-$ tut dicatat bahwa semakin besar suatu negara semakin besar perhatiannya terhadap sektor pendidikan. Negara-negara maju umumnya mengembangkannya merambat 
dari satu fase ke fase sejarah. Amerika misalnya, memandang pendidikan sebagai filosofi dasar berdemokrasi yang jika ditelusuri ke belakang sangat dipengaruhi oleh pioneer mereka seperti John Dewey. Dewey² menyebutkan bahwa pendidikan sebagai proses pembentukan kecakapan dasar secara intelektual dan emosional dapat dirumuskan sebagai teori umum yang tidak tersubordinasi oleh apapun.

Semangat sama dapat ditemukan dalam dasar bernegara Republik Indonesia. Dalam pembukaan UUD 45 disebutkan tujuan berbangsa adalah "mencerdaskan kehidupan bangsa". Prasa mencerdaskan menunjukkan betapa para founding fathers sejak awal melihat kunci survive bangsa ini adalah pendidikan. Jika dua bangsa ini, Amerika dan Indonesia dibandingkan, terlihat dua jalan berbeda orientasi pengembangan pendidikan masing-masing. Amerika modern memandang pendidikan sebagai bagian penting dari pembangunan ekonomi, sementara Indonesia sebaliknya, ekonomi adalah bagian penting bagi pembangunan pendidikan.

Pengabaian sektor pendidikan membawa bangsa akan jatuh ke dalam krisis "kecerdasan" akut. Degradasi kecerdasan jelas membawa bangsa ini terpuruk ke dalam krisis sosial berkepanjangan. Bagi Soedijarto, ${ }^{3}$ fenomena itu mensendat hasrat membangun peradaban negara bangsa yang modern yang telah tertinggal sekitar 400 tahun diukur dari persyaratan penyelenggaraan suatu kehidupan negara bangsa yang bermartabat.

Isu pembangunan karakter adalah adalah konsekuensi logis dari degradasi kecerdasan berbangsa. Karakter adalah pemahaman komprehensif atas makna etika, moral atau akhlak yang dapat ditelusuri melalui ajaran agama atau filsafat. Seperti halnya filsafat, semua agama mengajarkan kebaikan atau keutamaan dan semuanya mengantar pada suatu universalitas kebaikan. Universalitas kebaikan dapat dipahami sebagai adanya nilai dasar dimana setiap agama, ideologi dan kebudayaan memiliki kesamaan cara pandang tentang kebaikan.

Istilah karakter yang melekat di dalam konsepsi kebaikan, diadaptasi dari kata dalam bahasa Yunani, charassein yang berarti mengukir di atas benda keras seperti permata atau di atas permukaan besi yang keras. Dari kata itu berkembang pengertian karakter yang dimaknai sebagai tanda khusus pada pola perilaku (pattern of behavior) atau moral konstitusi. ${ }^{4}$

Pendidikan adalah unsur terpenting dalam pembangunan karakter, baik individu maupun masyarakat. Driyakara mendefenisikan pendidikan sebagai upaya memanusiakan manusia muda. Makna memanusiakan manusia muda lebih lanjut disebutkan sebagai proses mengangkat manusia muda ke taraf insani. Manusia muda, seperti disebut oleh Langeveld, adalah fase pertumbuhan manusia hingga usia dewasa. Proses "memanusiakan" menjadi orientasi proses didik agar anak mencapai taraf insani (mature) yang dapat memenuhi kebutuhan hidupnya di kemudian hari.

Tujuan pendidikan seperti dikemukakan Sokrates adalah untuk membuat manusia menjadi baik dan cerdas (to be good and smart). Kebaikan (goodness) adalah pengetahuan itu sendiri. Menjadi baik atas sesuatu adalah wujud nyata (matter) pengetahuan. ${ }^{5} \mathrm{Hal}$ ini menjelaskan bahwa kebajikan adalah bagian integral ke" bijak" an 
yang tidak dapat dipisahkan secara sendiri-sendiri. Secara lebih makro, Plato menyebut kecakapan negarawan bertujuan untuk kebajikan. Dalam kaitan itu, Plato melihat kata kuncinya ada pada dunia pendidikan yang akan mentransformasi moral dan pedoman yang jelas agar setiap orang dapat mengaplikasikan nilai kebajikan secara benar. ${ }^{6}$

Filosof Tiongkok, Konfusius menegaskan bahwa pendidikan adalah pundamental membangun masyarakat melalui individu-individu. Semakin banyak individu yang terdidik secara moral dan pengetahuan akan semakin tumbuh berkembang kebajikan di dalam masyarakat. Menurutnya seyogyanya setiap individu melatih diri untuk bajik (virtue) melalui pilar-pilar pendidikan moral. ${ }^{7}$

Arti penting pendidikan dalam mempengaruhi perkembangan individu terletak pada dua aspek utama kebaikan (virtue) yang bersifat intelektual dan moral. ${ }^{8}$ Kebaikan intelektual (intellectual virtue) adalah kemampuan alamiah (nature) yang dimiliki individu untuk memilih suatu orientasi. Sedangkan Kebaikan moral (moral virtue) berkembang melalui pengalaman dan pembelajaran (nurture). Dalam perspektif pendidikan, dua aspek tersebut tidak bisa dipisahkan dalam pembentukan karakter individu. Kebaikan intelektual menyiapkan kondisi mental dimana individu dapat memahami dan memilih suatu orientasi secara benar. Demikian pula, kebaikan moral akan menshahihkan tindakan-tindakan yang baik sehingga menjadi ciri kepribadian dalam berperilaku.

Intinya, telaah hakiki pembelajaran perlu dilakukan secara terus menerus. Kebutuhan studi pembelajaran penting oleh karena pembelajaran tidak dapat dipandang sebagai proses transmisi pengetahuan semata-mata, melainkan proses multi sisi (multifaceted) yang melibatkan semua komponen diri individu baik bawaan maupun yang berkembang melalui pengalaman. ${ }^{9}$ Kompleksitas cara belajar manusia, dengan otak yang dimilikinya, berlangsung dalam struktur tak terbatas dan penuh misteri, ${ }^{10}$ yang secara mikro menuntut kecerdasan individu (orang dewasa) untuk memilih jenis dan prosedur yang tepat untuk kegiatan pembelajaran yang lazim dikenal dengan sebutan strategi pembelajaran.

Strategi pembelajaran secara substansial adalah pendekatan menyeluruh dari jenis dan prosedur yang menyertai pembelajaran. Romiszowski, seperti dikutif Miarso, ${ }^{11}$ membedakan dua strategi dasar, yaitu expository (penjelasan) dan discovery (penemuan). Kedua strategi itu dapat dipandang sebagai dua ujung yang berlawanan dalam suatu kontinum strategi dimana di antara keduanya terdapat sejumlah strategi lain.

\section{METODE PENELITIAN}

Penelitian ini bertujuan untuk mendeskripsikan atau mengungkap makna yang terkandung di dalam permasalahan penelitian. Makna diungkapkan secara deskriptif analitik berdasarkan fakta melalui fenomena-fenomena di lapangan yang teramati. Fenomena-fenomena yang diamati dan ditelusuri melalui wawancara mendalam dan observasi serta studi dokumen mengenai penyelenggaraan pembelajaran di perguruan tinggi, khususnya di UIN Alauddin Makassar. 
Penelitian ini dilatari oleh pranata sosial akademik yang hidup di dalam kampus, khususnya yang berhubungan dengan aktifitas perkuliahan baik di dalam kelas maupun di luar kelas. Bagi dosen, penelitian ini difokuskan pada inovasi dan kemampuan mengadopsi hal-hal baru yang berpengaruh pada keterampilan mereka mendesain dan mengembangkan perkuliahannya sehingga dapat mencapai tujuan secara optimal.

Penelitian ini menggunakan metode atau pendekatan kualitatif, paradigma fenomenologis, dengan desain studi kasus. Kualitatif merupakan suatu paradigma penelitian untuk mendeskripsikan peristiwa, perilaku orang atau suatu keadaan pada tempat tertentu secara rinci dan mendalam dalam bentuk narasi. Deskripsi peristiwa atau keadaan tersebut menurut Bogdan dan Biklen12 berdasarkan sifat kealamiahan setting dan sumber data sesuai dengan karakteristik paradigma kualitatif itu sendiri.

\section{HASIL PENELITIAN}

Sebagai perwujudan dari kegiatan belajar, pembelajaran membutuhkan rangkaian studi cermat agar rumusan instruksional yang ditetapkan mempunyai nilai fungsional tinggi dalam mencapai tujuan pembelajaran. Dalam berbagai sisi, keperluan tersebut terasa penting oleh karena perkembangan pembelajaran tidak bisa dilepaskan dari faktor-faktor perkembangan dunia sosial yang, langsung atau tidak langsung, berpengaruh pada cara-cara manusia berpikir, bertindak, dan belajar. Reigeluth menggambarkan perubahan tersebut seperti terlihat dalam tabel 1.1.

Tabel 1.1

Perbedaan utama antara era industri dan era informasi terhadap pendidikan

\begin{tabular}{ll}
\multicolumn{1}{c}{ ERA INDUSTRI } & \multicolumn{1}{c}{ ERA INFORMASI } \\
\hline - Hubungan adversarial & - Hubungan kerja sama \\
- Organisasi birokratik & - Organisasi tim \\
- Kepemimpinan otokratik & - Kepemimpinan berbagi (shared) \\
- Kontrol terpusat & - Otonomi dan akuntabiliti \\
- Otokrasi & - Demokrasi \\
- Demokrasi keterwakilan & - Demokrasi partisipatif \\
- Kerelaan & - Inisiatif \\
- Komunikasi satu arah & - Networking \\
- Kompartemental (divisi kerja) & - Holisme (tugas terintegrasi) \\
\hline
\end{tabular}

Tabel 1.1 menggambarkan kecenderungan sosial global yang berimplikasi kepada perubahan-perubahan mendasar di dalam dunia pendidikan. Jika sekolah sebelumnya berada pada level mayor untuk menciptakan masyarakat setara dan produktif, kini juga berfungsi melayani dan mereproduksi hubungan sosial, ekonomi dan politik. Bahkan beberapa perspektif telah menempatkan sekolah sebagai silent factor dalam meletakkan dan menjaga prinsip-prinsip hidup dan melepaskan ketergantungan individu di dalam kehidupan sosial. Disebut demikian karena sekolah didesain untuk mentransmisi nilai-nilai bermasyarakat ke dalam kurikulum baik kul- 
tural, intelektual maupun norma-norma estetis dan standar atau lebih dikenal dengan the hidden curriculum. ${ }^{13}$

Secara nasional, UU RI No. 20 tahun 2003 tentang Sistem Pendidikan Nasional telah merubah fundamental pendidikan dari etatisme ke pemberdayaan dimana unit terkecil pembelajaran berkekuatan untuk mengembangkan metode, strategi maupun taktik untuk mencapai tujuan pembelajaran yang sesuai dan dibutuhkan. ${ }^{14}$ Amanat pemberdayaan tersebut diapresiasi dengan konsep desentralisasi yang dibutuhkan agar koherensi berbagai faktor yang berpengaruh dalam pembelajaran maujud dan sinergis dalam efisiensi pencapaian tujuan pendidikan.

Persoalannya, pembelajaran bukanlah semata deskripsi proses melainkan preskripsi yang tertuang di dalam perencanaan pembelajaran yang holistik serta dapat digunakan secara praktis di dalam kelas. Jika pembentukan karakter menjadi orientasi, maka proses pembelajaran harus dikawal sejak proses perencanaan hingga penyelenggaraannya sehingga pencapaian tujuan dapat optimal. Titik kritis perencanaan pembelajaran terletak pada transmisi perlakuan atas perilaku belajar yang diharapkan. Berbagai studi menunjukkan bahwa pengajar (guru ataupun dosen) seringkali mengabaikan aspek-aspek pundamental pencapaian perilaku minimal belajar. Jika diamati, tingkat pencapaian level analisis yang menjadi level minimal dalam ranah kognitif amatlah rendah. Pada umumnya ranah ini hanya berakhir pada perilaku di bawah perilaku analisis dan hanya $48 \%$ yang sampai pada level tersebut.

Akan halnya ranah afeksi. Gambar 1 menunjukkan frekuensi ketuntasan afeksi adalah 32\%. Hal tersebut menunjukkan kesulitan yang dialami oleh dosen untuk mencapai perlakuan afeksi secara optimal. Pada ranah ini umumnya berhenti pada level penghargaan nilai atau berada dua level di bawah level maksimal Bloom. Seperti halnya ranah afeksi, pada ranah psikomotor juga menunjukkan kelemahan terutama pada perencanaan yang pada umumnya berhenti pada level ketepatan, atau dua level di bawah level minimal pembelajaran tinggi yaitu naturalisasi. Selengkapnya, distribusi frekuensi ketuntasan level pembelajaran dapat dilihat pada histogram 1.

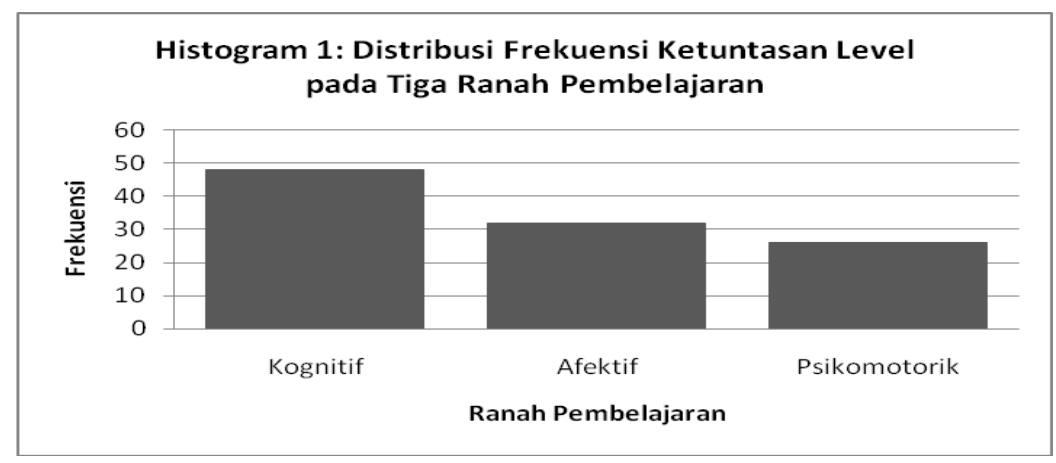

Gambar 1.

Frekuensi Ketuntasan Level Pembelajaran

Capaian level pada domain kognitif rata-rata berhenti pada level aplikasi dan hanya sedikit yang sampai pada level analisis. Secara teori, level analisis adalah level 
minimal yang wajib dicapai di dalam pembelajaran. Artinya, jika suatu rancangan pembelajaran tidak sampai ke level analisis, maka dipastikan pencapaian tujuan pembelajaran tidak terpenuhi. Pada tingkat perkuliahan di perguruan tinggi, semestinya berada di atas level analisis karena perkuliahan berada pada level belajar tinggi yang menuntut belajar dengan berpikir tinggi (high order thinking).

Pada domain afeksi menunjukkan tingkat ketuntasan yang lebih rendah dengan persentase $35 \%$. Domain afektif rata-rata berhenti pada level pemberian respon (A2) yang relatif seimbang dengan level penghargaan nilai (A3). Padahal, secara teori capaian minimal domain afektif berada pada level pengalaman (A5). Ditemukan bahwa secara keseluruhan dosen tidak terlatih menganalisis kebutuhan afektif ke dalam perkuliahan hingga level A5.

Kelemahan dalam mengorganisasi pengetahuan berakibat pada lemahnya pondasi afektif yang berujung pada pengalaman. Akibat langsung pada ketidakmampuan mengorganisasi pengetahuan adalah pengetahuan dengan sendirinya tidak akan menjadi bagian dari pengalaman individu. Akibatnya, mahasiswa mengalami persoalan toleransi akademik, yakni kemampuan mengadaptasi pengetahuan dan keterampilan yang dia miliki terhadap pengetahuan dan keterampilan yang terdapat pada orang lain. Secara umum problem toleransi mahasiswa dapat dikemukakan sebagai berikut:

1. Toleransi lintas disiplin.

2. Toleransi lintas budaya.

3. Toleransi lintas komunitas.

4. Toleransi lintas organisasi.

5. Toleransi lintas keyakinan.

Problem toleransi lintas disiplin memunculkan egoisme disiplin dimana jurusan-jurusan tertentu dianggap lebih baik dari jurusan yang lain. Misalnya, jurusan eksakta seperti biologi, kimia, matematika merasa lebih baik dari jurusan fokasional seperti teknik informatika, teknik perencanaan dan tata kota, dan lain-lain. Dalam jurusan sosial, mahasiswa jurusan bahasa Inggris memiliki ego jurusan lebih baik dari jurusan bahasa Arab, PAI, sejarah, dan lain-lain. Egoisme disiplin ilmu melemahkan maksimalisasi pengorganisasian pengetahuan dan keterampilan mahasiswa. Anehnya, egoisme serupa juga muncul dari jurusan sebaliknya sehingga jika tidak terkelola dengan baik berpotensi untuk memunculkan persaingan yang tidak sehat.

Toleransi lintas budaya juga lemah. Sebagian mahasiswa akan menganggap suatu kebiasaan pada kelompok mahasiswa yang tidak biasa dia temukan sebagai "cacat" budaya. Pada umumnya cacat budaya muncul pada kebiasaan-kebiasaan ekspresif seperti pola linguistik. Tidak jarang karena perbedaan ekspresi menguatkan sentimen kebudayaan yang berpotensi chaos di kemudian hari. Kelemahan pada toleransi lintas komunitas adalah konsekuensi dari lemahnya toleransi lintas budaya.

Komunitas mahasiswa dapat dikenali dengan ciri-ciri tertentu, seperti: kesamaan aktifitas (seperti aktifitas organisasi dan minat tertentu), kesamaan atribut (seperti atribut organisasi sektoral: organisasi daerah asal, afiliasi ideologi, aliran beladiri, ke- 
lompok media sosial, dll), kesamaan kecenderungan (kelompok belajar, kelompok keprihatinan spesifik, dll).

Kelemahan lain ditemukan pada kemampuan menyinergikan berbagai komponen desain perkuliahan. Yang paling mencolok terlihat pada kesesuaian antara rumusan tujuan dengan keputusan di dalam item strategi pembelajaran. Gambar 2 menunjukkan lemahnya desain terutama pada bagian yang menjadi inti desain perencanaan mengajar seperti kejelasan target perkuliahan, analisis konten perkuliahan, target setiap item perkuliahan, variasi metode dan ketepatan evaluasi.

Dalam menetapkan metode misalnya, dosen belum sepenuhnya bisa melepaskan diri dari sentral kelas sehingga mahasiswa lemah di dalam mengkonstruksi pengetahuannya secara mandiri. Begitu juga pilihan media, akuisisi media populer sedemikian diadopsi tanpa analisis kebutuhan yang memadai. Penggunaan media elektronik seringkali menjadi jebakan sehingga komputer bukannya digunakan untuk belajar (learning with) melainkan dipelajari (learning to) sebagai suatu materi pokok. Deskripsi kejelasan komponen desain dapat dilihat pada histogram 2.

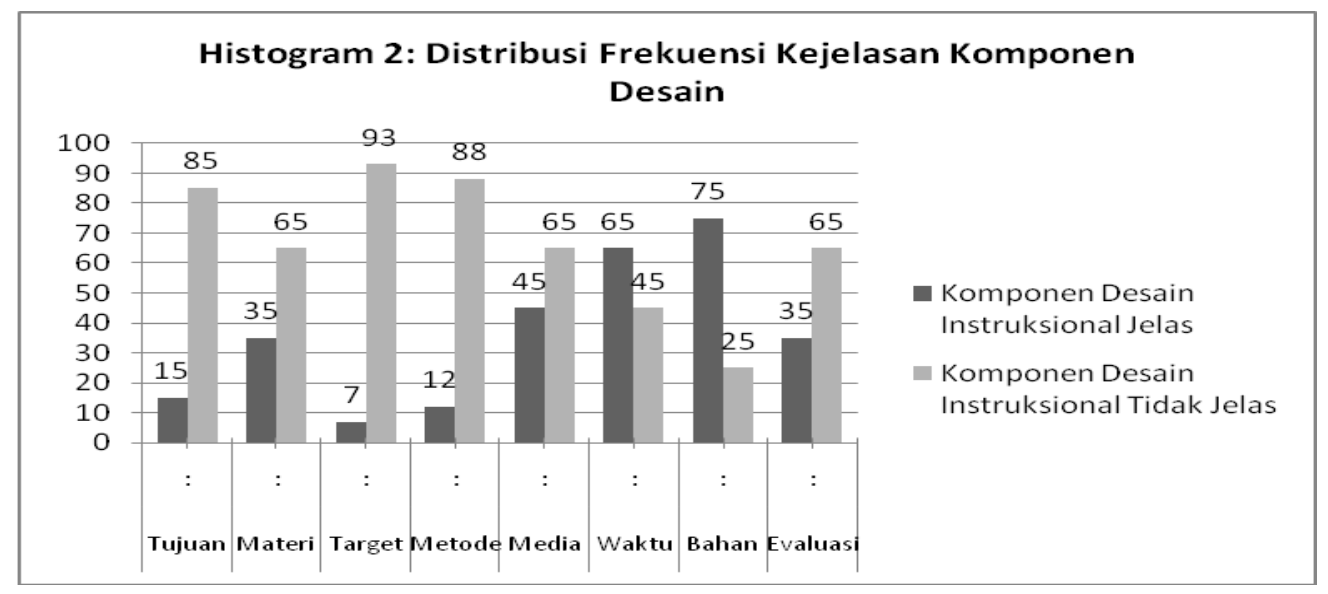

Gambar 2.

Deskripsi Kejelasan Komponen Desain

Gambar 2 menunjukkan jawaban mahasiswa terhadap jelas tidaknya delapan komponen desain pembelajaran disampaikan oleh dosen dalam perkuliahan. Hanya $15 \%$ mahasiswa yang menjawab bahwa rumusan tujuan disamaikan secara jelas oleh dosen, sedang sisanya, 85 menyatakan tidak jelas. Pada komponen materi, terdapat $65 \%$ yang menjawab komponen tersebut jelas disampaikan oleh dosen dan sisanya, $35 \%$ menjawab tidak jelas. Sedikit sekali dosen yang menyampaikan target yang dicapai dalam perkuliahan, sisanya 93\% mengatakan komponen ini tidak jelas. Kejelasan komponen metode juga didominasi oleh jawaban yang menyatakan tidak jelas sebesar $88 \%$. Kejelasan penggunaan media dinyatakan sebesar $45 \%$ dan sisanya, $65 \%$ menyatakan tidak jelas. Komponen waktu dinyatakan sudah jelas sebesar $65 \%$ dan $45 \%$ menyatakan belum jelas. Komponen bahan ajar, 75\% menyatakan jelas, sisanya 
$25 \%$ menyatakan tidak jelas. Komponen evaluasi, 65\% menyatakan belum jelas, sisanya $35 \%$ menyatakan telah jelas.

Deskripsi gambar 2 di atas menunjukkan desain pada delapan komponen instruksional masih lemah dilakukan oleh dosen. Keadaan tersebut jelas melemahkan proses pencapaian tujuan pembelajaran. Diperlemah lagi oleh lemahnya kemampuan menjabarkan atau mengembangkan perilaku belajar sosial, kreatif, dan lain-lian. Sangat jarang atau bahkan tidak ditemukan ada rancangan yang menetapkan perilaku sosial seperti dapat menerima, mengakui, menyetujui, membantu, menyumbang, memuji, menolong, menolak, memaafkan, menyambut, mengundang, menggabung, mengizinkan, tersenyum, berterimakasih, berkunjung, bersukarela, dan lain sebagainya. Padahal perilaku-perilaku tersebut adalah soft-skills yang dibutuhkan untuk membangun kepribadian yang tangguh.

Gambar 2 juga menjelaskan perubahan "perilaku" mengajar dosen perlu diperbaiki dengan cara lebih banyak berlatih mengembangkan kemampuan perencanaan perkuliahan secara konstruktif. Di antara beberapa model, peneliti merekomendasikan perkuliahan aktif sebagai model untuk mengembangkan desain perkuliahan yang dapat mendorong berkembangnya karakter akademik mahasiswa. Gambaran tentang pembelajaran aktif di perguruan tinggi didasarkan pada prinsip bahwa cara belajar terbaik mahasiswa adalah dengan melakukan, dengan menggunakan semua inderanya, dan dengan mengeksplorasi lingkungannya yang terdiri atas orang, hal, tempat, kejadian nyata atau dengan kata lain lebih kontekstual dan berbasis problem solving.

Keterlibatan aktif dengan lingkungan sosial dan fisik serta gagasan yang berkait dengan kehidupan nyata akan mendorong mahasiswa aktif berpikir untuk mendapatkan pengetahuan baru dan memadukannya dengan pengetahuan yang sudah dimilikinya. Untuk memfasilitasinya, dosen harus menggunakan berbagai strategi yang aktif dan kontekstual, melibatkan pembelajaran bersama (cooperative learning) dan mengakomodasi perbedaan gender dan gaya belajar masing-masing individu.

Penerapan pendekatan tersebut di dalam perkuliahan membutuhkan beberapa strategi dimana dosen seharusnya:

1. Merubah cara pandang terhadap cara menyampaikan informasi perkuliahannya agar lebih lebih terencana dan teliti berdasarkan tujuan yang jelas yang memungkinkan untuk dicapai oleh mahasiswa.

2. Membuka ruang bagi mahasiswa untuk belajar secara aktif dan menerapkan pembelajarannya dalam berbagai cara berdasarkan konteks kehidupannya yang nyata.

3. Pengelola perguruan tinggi hendaknya mengelola lingkungan belajar sehingga terasa nyaman dan tidak menakutkan, fokus pada belajar dan mengayomi sehingga dapat mengoptimalkan waktu, perilaku dan sumber daya yang mendukung pembelajaran aktif.

4. Melakukan evaluasi atas hasil belajar mahasiswa berdasarkan penguasaan keterampilan dan pengetahuan serta kemampuannya menggunakan keterampilan dan pengetahuannya di dalam kehidupan nyata (authentic assesment) selama berada di dalam perkuliahan. 
Dalam kaitannya dengan pengembangan karakter akademik sangat ditentukan oleh ketepatan memilih konten, bahan ajar serta proses belajar. Konten atau isi perkuliahan bisa dipilih berdasarkan kebutuhan kontekstual individu. Dengan pilihan konten yang tepat serta percaya kepada kemampuan mahasiswa untuk merekonstruksi bahan ajar yang diperolehnya, kita berharap akhirnya mahasiswa akan mampu menemukan dan menyusun pengetahuannya secara mandiri. Proses perkuliahan tentu sangat berperan di dalam upaya itu.

Berbicara tentang proses belajar, maka ada tiga teori yang dapat dikemukakan sebagai pertimbangan pengembangan instruksional. Tiga teori tersebut adalah: (1) teori perkembangan Piaget, (2) teori kognitif Bruner, dan (3) teori bermakna Ausubel.

Secara umum aplikasi teori perkembangan Piaget biasanya mengikuti pola desain seperti berikut ini:

1. Menentukan tujuan-tujuan instruksional.

2. Memilih materi perkuliahan

3. Menentukan topik-topik yang mungkin dipelajari secara aktif oleh mahasiswa.

4. Menentukan dan merancang kegiatan belajar yang sesuai dengan topik-topik yang akan dipelajari oleh mahasiswa, biasanya berbentuk eksperimentasi, problem solving, roleplay, dan sebagaianya.

5. Mempersiapkan berbagai pertanyaan yang dapat memacu kreatifitas mahasiswa untuk berdiskusi atau bertanya.

6. Mengevaluasi proses dan hasil belajar.

Sementara aplikasi teori kognitif Bruner biasanya mengikuti pola sebagai berikut:

1. Menentukan tujuan-tujuan instruksional.

2. Memilih materi pelajaran atau perkuliahan.

3. Menentukan topik-topik yang bisa dipelajari secara induktif oleh mahasiswa.

4. Mencari contoh-contoh, tugas, ilustrasi, dsb. yang dapat digunakan mahasiswa untuk belajar.

5. Mengatur topik-topik pelajaran sedemikian rupa sehingga urutan topik itu bergerak dari yang paling konkrit ke yang paling abstrak, dari yang paling sederhana ke yang paling kompleks, dari tahap enaktif, ikonik, sampai ke tahap simbolik, dan seterusnya.

6. Mengevaluasi proses dan hasil belajar.

Untuk mendesain teori bermakna Ausubel, secara umum dipraktekkan mengikuti sistimatika seperti berikut:

1. Menentukan tujuan-tujuan instruksional.

2. Mengukur kesiapan mahasiswa.

3. Memilih materi pelajaran dan mengaturnya dalam bentuk penyajian konsep-konsep kunci.

4. Mengidentifikasi prinsip-prinsip yang harus dikuasai mahasiswa dari materi tersebut.

5. Menyajikan suatu pandangan secara menyeluruh tentang apa yang harus dipelajari. 
6. Membuat dan menggunakan "advance organizer", paling tidak dengan cara membuat rangkuman terhadap materi yang baru saja diberikan, dilengkapi dengan uraian singkat yang menunjukkan relevansi antara materi yang sudah diberikan dengan materi akan diberikan.

7. Mengajar mahasiswa memahami konsep-konsep dan prinsip-prinsip yang sudah ditentukan, dengan memberi fokus pada hubungan yang terjalin antara konsepkonsep yang ada.

8. Mengevaluasi proses dan hasil belajar.

Gambar 3: Analisis Kinerja Belajar yang Rendah

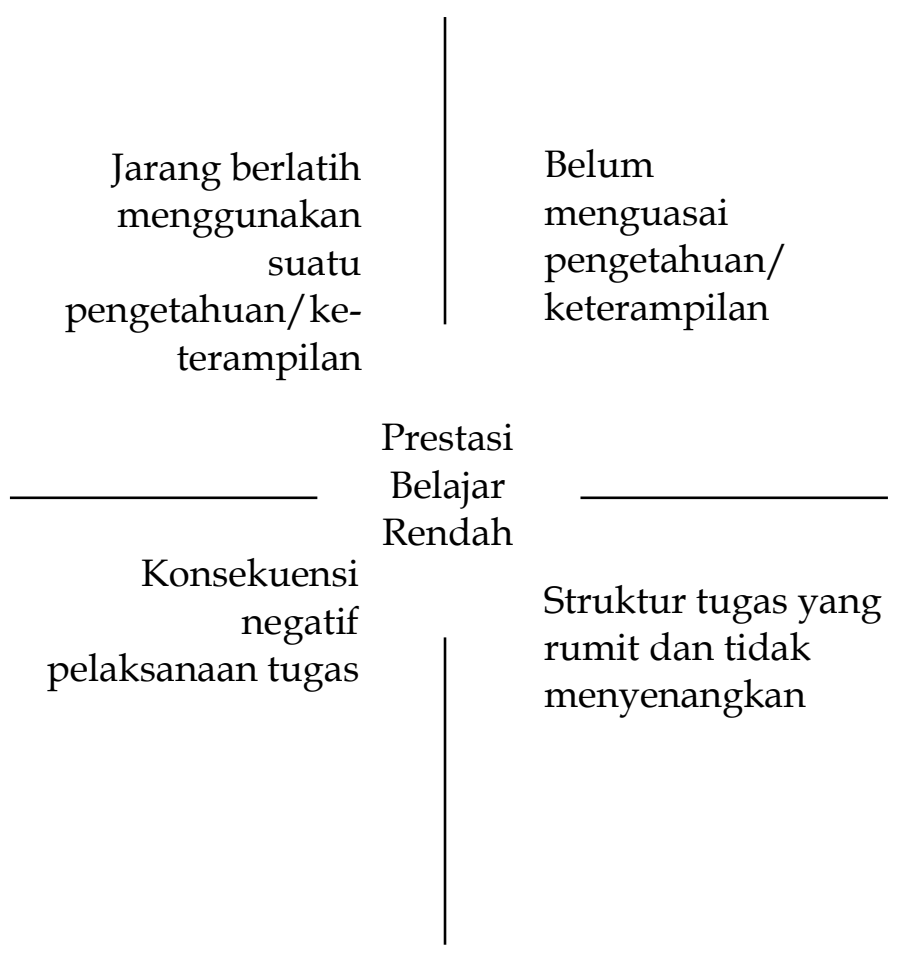

Desain perkuliahan sesungguhnya tidak tunggal mempengaruhi kesuksesan perkuliahan. Oleh karena itu, di dalam prakteknya sebaiknya juga mempertimbangkan unsur-unsur psikologis seperti motivasi dan ketangguhan diri (self-eficacy) mahasiswa. Berbagai studi menunjukkan kinerja belajar rendah disebabkan oleh faktor-faktor latihan, penguasaan, konsekuensi pelaksanaan tugas dan kerumitan struktur tugas (lihat gambar 3).

Gambar 3 menunjukkan bahwa prestasi belajar rendah disebabkan oleh empat aspek. Aspek pertama adalah kurangnya latihan menggunakan suatu pengetahuan atau keterampilan yang mendorong lemahnya penguasaannya. Pada dasarnya suatu pengetahuan atau keterampilan akan meningkat jika digunakan, baik dalam situasi simulatif maupun dalam keadaan nyata. Intensitas latihan akan mendorong penguasaan lebih pengetahuan dan aspek kedua penyebab rendahnya prestasi belajar dapat 
teratasi. Penguasaan pengetahuan atau keterampilan penting artinya untuk mendorong peningkatan motivasi belajar.

Penguasaan pengetahuan atau keterampilan mendorong penguasaan pengalaman belajar (mastery experience). Penguasaan pengalaman akan mendorong kepercayaan diri yang pada akhirnya meningkatkan kemampuannya belajar. Percepatan penguasaan pengalaman dipengaruhi berbagai faktor. Di dalam pembelajaran, faktor tugas substansial untuk mendukung penguatan optimalisasi penguasaan suatu kompetensi. Struktur tugas yang rumit dan tidak menyenangkan berakibat pada prestasi belajar rendah. Artinya, selain penguasaan pengalaman, desain struktur tugas perlu diperhatikan sehingga penguasaan pengalaman dapat dicapai secara optimal. Struktur tugas yang baik misalnya dapat didesain dengan prinsip-prinsip elaborasi, yaitu perangkaian materi tugas yang disusun sistimatis mengikuti derajat kesulitannya. Agar pebelajar mencapai tugas yang kompleks dan rumit, agar diawali dengan tugastugas yang lebih mudah dan sederhana.

Strategi yang disebut terakhir dapat mengantisipasi konsekuensi negatif pelaksanaan tugas. Atensi terhadap tugas perlu didorong melalui struktur tugas yang sekunsal atau berantai dimulai dari yang paling nyata hingga yang paling abstrak, paling sederhana hingga yang paling kompleks, atau dari yang paling kecil hingga yang paling besar. Strategi ini dalam berbagai riset menunjukkan dapat memfasilitasi timbulnya atensi penyelesaian tugas.

\section{SIMPULAN}

Membentuk karakter dalam perspektif pembelajaran tidak bisa dilepaskan dari pilihan strategi di dalam kelas. Semakin tepat strategi yang dipilih akan semakin memperkuat dan mempercepat transformasi nilai-nilai ke dalam diri individu-individu dan akhirnya masyarakat. Kebutuhannya tentu adalah maksimalisasi dukungan pembelajaran. Penyelenggaraan pendidikan tidak bisa menomorduakan kelas karena kelas adalah refresentasi utama lembaga pendidikan yang belajar. Kuat lemahnya kelas mencitrakan kuat lemahnya lembaga pendidikan, dan pada akhirnya suatu bangsa.

Desain pembelajaran di dalam kelas tidak bisa dilepaskan dari unsur-unsur kelas terutama manusia yang ada di dalamnya (dosen dan mahasiswa) serta pendukungnya yang lain seperti lingkungan belajar, bahan ajar serta sumber belajar. Kecermatan di dalam memanfaatkan unsur-unsur tersebut akan mendorong perkuliahan akan lebih baik dan dipercaya mampu menciptakan kepribadian mahasiswa sehingga menjadi mahasiswa dengan karakter akademik yang tangguh.

\section{CATATAN AKHIR}

1. William F. O'neil, Educational Ideologies; Contemporary Expres-sions of Educational Philosophies, California: Goodyear Pub-lishing Company, 1981, h. 12.

2. John Dewey, Democracy and Education, New York: Macmilan Co., 1916, h. 87. 
3. Soedijarto, Pendidikan Nasional sebagai Wahana Mencerdaskan Bangsa dan Membangun Peradaban Negara-Bangsa, Jakarta: Center for Information and National Policy Studies, 2000, h. 89.

4. Karen E. Bohlin, et all., Building Character in school resource Guide, San Fransisco: Jossy Bass, 2001, h. 3.

5. Grube, Plato's Thought, Hacket Publishing Company, 1980, h. 216 - 217.

6. Ibid.

7. Yang Huanyin, Confusius dalam http//www.ibe.unesco.org, h. 3. Diunduh pada 3 Oktober 2011.

8. Charles Hummet, Aristotle, dalam http//www.ibe.unesco.org., h. 2.

9. Margareth E. Gredler, Learning and Instruction, Theory and Practice, (6 $6^{\text {th }}$ Edition; New Jersey: Pearson, 2009), h. 2.

10. David A. Sousa, How The Brain Learns, California: Corwin Press, 2006, h. 1.

11. AJ. Romiszowski, Producing Instructional System: Lesson Planning for Individualized and Group Learning Activities, New York: Nichols Publishing Company, 1984, h. 56.

12. Bogdan dan Biklen, Qualitative Research in Education: An Introduction to Theory and Methods, Boston: Allyn and Bacon, Inc., 1998, h. 142.

13. Harold Entwistle, Class, Culture and Education, London: University of Cambridge, 1979, h. 51.

14. Yusufhadi Miarso, Menyemai Benih Teknologi Pendidikan, Cet. IV; Jakarta: Kencana, 2009, h. 531.

\section{DAFTAR PUSTAKA}

Bogdan dan Biklen. Qualitative Research in Education: An Introduction to Theory and Methods, Boston: Allyn and Bacon, Inc., 1998.

Bohlin, Karen E. et al. Building Character in School Resource Guide. San Fransisco: Jossy Bass, 2001.

Dewey, John. Democracy and Education. New York: Macmilan Co., 1916.

Entwistle, Harold. Class, Culture and Education. London, University of Cambridge, 1979.

Gredler, Margareth E. Learning and Instruction, Theory and Practice. $6^{\text {th }}$ Edition; New Jersey: Pearson, 2009.

Grube, Plato's Thought. Hacket Publishing Company, 1998.

Huanyin, Yang. Confusius dalam http/ / www.ibe.unesco.org, Diunduh pada 3 Oktober 2011.

Hummet, Charles. Aristotle, dalam http/ / www.ibe.unesco.org. Diunduh pada 3 Oktober 2011. Miarso, Yusufhadi, Menyemai Benih Teknologi Pendidikan. Cet. IV; Jakarta: Kencana, 2009.

O'neil, William F. Educational Ideologies; Contemporary Expres-sions of Educational Philosophies. California: Goodyear Publishing Company, 1981.

Peraturan Pemerintah RI Nomor 25 Tahun 2005 tentang Standar Nasional Pendidikan.

Romiszowski, AJ. Producing Instructional System: Lesson Planning for Individualized and Group Learning Activities. New York: Nichols Publishing Company, 1984.

Soedijarto, Pendidikan Nasional sebagai Wahana Mencerdaskan Bangsa dan Membangun Peradaban Negara Bangsa, Jakarta: Center for Information and National Policy Studies, 2000.

Sousa, David A. How The Brain Learns. California: Corwin Press, 2006.

Undang-Undang RI. Nomor 20 Tahun 2003 tentang Sistem Pendidikan Nasional. 